\title{
Environmental Cataclysm and the Eco-logics of Sustainability
}

\section{Ratul Nandi}

Assistant Professor, Department of English, Siliguri College, Siliguri, West Bengal, India mavslg@gmail.com

\begin{abstract}
The understanding of the word 'environment' has taken on complex valences in the present context of global environmental catastrophe and climate change. Faced with the imminent threat of extinction, one needs to stand back and question the very taxonomic construction of the word 'environment' as it has undergone epistemic, turbulent, and even schizophrenic transformation in a way we can now safely call ourselves as belonging to a distinct 'Carbon Generation'. Our everyday life activities are so interwoven with the increasing sense of environmental pollution that even the threats of global extinction do not appear drown us into wholesome paranoia. The paper attempts to argue that the only possible way out of the situation lies not only in the collective acknowledgement of our duty towards ecological preservative policies that draw us into actions, but a deep philosophical sense of our phenomenological existence with our environ is absolutely urgent if we are to do something about our current ecological crisis.
\end{abstract}

Keywords- Anthropocene, climate change, deep philosophical sense, ecological preservative policies, Phenomenogical existence.

\section{INTRODUCTION}

A concerted clamor is being heard at the corridor of our planet quite regularly: Nature is going to die, with all life in it. The sense of apocalypse which would eventually befall humanity is something that altered our sense of the planet we lovingly call our home. Threat of extinction now makes us question how far we have messed up our planet. That seemingly simple question has sparked a new battle between geologists and environmental advocates over what to call the time period we live in.Although we are officially still in the Holocene epoch, there is a growing consensus amongst the experts and scholars across the globe that the term has almost become outdated and replaced increasingly by what people now prefer to call the 'Anthropocene' epoch, an era in which the human as a collective unit has assumed a new geological proportion, a force now dominating every inch of our planet today.

So, here we are in a new era in which human beings have become synonymous with a geological force. And this has obvious impact on our environmental vocabulary. We are reluctant to call anything as 'Pure Nature' because we have come increasingly to realize that in a pristine unadulterated way perhaps there is no place left on the planet which is free from human interference. The thesis of Bill McKibben's famous book 'The End of Nature' (1989) is quite telling and completely in sync with the ethos of our present scenario: Nature is humanly mediated, hence we need to be more prosaic and urgently practical of our situation if we are to survive as a species. But the question is how have we responded to this imminent threat of extinction? What is our answer to the challenges posed by global warming, climate change, polar ice meltdown, and ozone layer thinning every day?

Surely, this is a kind of problem science cannot solve alone. It requires the Humanities disciplines to come forward with some of the spin-offs of their long held ideas. In contrast to the Social Sciences and Humanities, natural sciences are concerned with the study of voiceless and reified objects, which need to be absolutely defined and explained. To them, nature is just a matter of disinterested observation. As Mikhail Bakhtin says, that natural sciences are monological because they examine things as if they existed only for the single human mind rather than for the mind in relation to other minds. Natural sciences are based on mathematical accuracy and on precision of measurement. The Humanities and Social Science scholars are, on the other hand, more keen to see things liberated form this kind of reification. This hardening of scientific formulation adopted by Natural Sciences in effect makes us resort to a view of nature as something that needs to 
be protected, preserved and to be kept from the rapacious tendency of the human race to consume everything to its fullest. If our earth is facing its dire-most crisis ever, the only remedy lies not only in simple act of preservation of what is on the verge of extinction. The current ecological crisis of the earth should prove to us once and for all that keeping humans out of nature is next to impossible. The Anthropocene is itself a stark reminder that there is perhaps no nature that exits today which is free from human intervention.

As human beings have periodically destroyed their own habitat, the challenge lies in the not only in the way preserve our biosphere, but somehow to clutch onto some profound sense of ethical living that both grounds and sustains our methods of preservation in the first place. This ethical sense is not only about human saving the earth but a deep and complex sense of phenomenological existence in which human is not made to stand apart from his background of both animate and inanimate objects. This sense of the human being embroiled in the earth is one attitude that underlie all motivations of our 'save the earth' dictum. We can certainly re-enchant our ecological ethics if we, instead of blindly following preservation programmes, care to understand the complex way human is enmeshed into nature. German Philosopher Martin Heidegger is one thinker whose mediation on the question of proper ethical dwelling on earth may open up new Eco-logics nature and offer a therapeutic answer as to how should we re-think our relationship with nature.

A major critic of technology was German philosopher Martin Heidegger. Martin Heidegger's phenomenological analysis of human existence can contribute to environmental philosophy by overcoming the dualistic ontologies that have precluded the development of an understanding of nature that would encompass the needs of both human beings and the nonhuman world. For Heidegger, the most essential characteristic of human existence lies in our fundamental relation to being which occurs in our everyday interactions with the world around us, and is the source of the world of human existence. Heidegger uses the term Dasein to describe the essential relatedness of being and human existence and explains that ontology must begin with an understanding of the interconnectedness of Dasein and the world human beings find themselves in .In characterizing human existence as Dasein, Heidegger's thought has the potential to restore our understanding of the fitting place of human beings within nature in two ways. First, Heidegger's characterization of human existence as Dasein can clear the way for a fuller understanding of the interconnectedness and interdependence of the human and nonhuman world. Secondly, Heidegger's critique of Western metaphysics and modern technology recontextualizes our understanding of nature within the sphere of our practical experience and thereby has the potential to promote the development of authentic environmental concern. Heidegger understands modern technology as the defining mark of our relationship with being and the world around us. Therefore, his critique of modern technology and the theoretical attitude of modern science is yet another way in which Heidegger aims to elucidate and restore our understanding of our own human existence.

In "The Question Concerning Technology" (1953), Heidegger posited that the modern technological "mode of Being" was one which viewed the natural world, plants, animals, and even human beings as a "standing-reserve" - resources to be exploited as means to an end. To illustrate this "monstrousness", Heidegger uses the example of a hydroelectric plant on the Rhine river which turns the river from an unspoiled natural wonder to just a supplier of power. In this sense, technology is not just the collection of tools, but a way of Being in the world and of understanding the world which is instrumental and grotesque. According to Heidegger, this way of Being defines our modern way of living in the West. For Heidegger, this technological process ends up reducing beings to not-beings, which Heidegger calls 'the abandonment of Being' and involves the loss of any sense of awe and wonder, as well as an indifference to that loss. The culmination of this trend, in his view, is a globalizing technology with its threat, or promise, of 'limitless domination'. What has been termed a'productionist metaphysics' lies at the heart of this development, through which instrumental or technological modes of thought are projected outwards upon the world at large. The dialectic which Heidegger perceives between concealment and a 'clearing' of being is neglected in favor of a world of useable or calculable objects 'ready-at-hand'. For Heidegger, understanding being in this way would allow us to grant the beings we encounter their independence beyond their ability to conform to the framework of modern technology and would allow us to encounter them as "things" rather than simply as the objects of modern science and technology. Interpreting beings in a way that grants them their independence and selfstanding brings us into a relation with being which Heidegger describes as "poetic dwelling". Heidegger's description of poetic dwelling describes the meditative involvement with the world around us that would allow nature to become meaningful for us beyond the sphere of modern science and technology and to come into our understanding as an essential part of human existence. 
Heidegger begins his examination of modern technology by examining its origins in early Greek thought. He explains that the word technologye comes from the early Greek word, techne, which described the activities of craftsmen, the arts of the mind, and the fine arts. For the early Greeks, techne and phusis were regarded as the two complementary aspects of poiesis, which means to bring forth out of concealment, whether through phusis, or through the hands of human beings. According to Heidegger, the Greeks described this bringing forth into unconcealment as a form of revealing, aletheia, the coming forth of truth. Understanding technology in this way opens an entirely new realm of its essence. As Heidegger says, "It is the realm of revealing, i.e. of truth." Therefore, modern technology must be understood as more than mere technics; it is the culmination of Western metaphysics and constitutes the framework through which we interpret and interact with the world around. Hence as we see Heidegger talks about technology in both senses: both as destructive and life-affirming.

\section{CONCLUSION}

True, this way of thinking may not help avert the eventual crisis that awaits the planet. But at least it can lead us into path away from the destructive alley of our thought founded uncritically upon the hidden anthropocentrism of our collective thinking. This tendency ultimately leads to the inherent violence of our basic assumption of life which eventually sees the 'human' as, to borrow a phrase from Neil Everndon, a "natural alien" to its immediate environment into which he finds himself. This propensity to see itself alienated from nature has catastrophic philosophical consequences for us. This is now being manifested in the form of ultimate threat of extinction not only of the human race but the entire earth- a moment which is difficult to reverse. Hence we need to bring about changes in our attitudes first, rather than asking people to "go green". We have to realize at some moment that our global ecological crisis is something for which we are also responsible. However, assuming responsibility does not mean punishing the human for living so violently as to consume up all resources of the planet. What we need at this moment is to re-orient the basic cornerstones of our thinking and re-think new eco-logics of nature that would readily welcome a meaningful co-existence of all life forms, including the human.

\section{REFERENCES}

[1] Beck, Ulrich. (1998). Risk Society: Towards a New Modernity (London: Sage, 1992).World Risk Society: Cambridge, MA: Polity

[2] Demerit, David, 'The Construction of Global Warming and the Politics o Science', Annals of the Association of American Geographers 91 (2001)

[3] Gifford, Terry. Pastoral (1999). A study of the various sense and histories of the genre: London: Routledge Thiele, Leslie Paul, 'Nature and Freedom: A Heideggerian Critique of Biocentric and Socio centric Environmentalism', Environmental Ethics 17 (1995)

[4] Zimmerman, Michael, Contesting Earth's Future: Radical Ecology and Postmodernity (Berkeley: University of California Press, 1994) 